\title{
Front Matter: Volume 11602
}

, "Front Matter: Volume 11602," Proc. SPIE 11602, Medical Imaging 2021: Ultrasonic Imaging and Tomography, 1160201 (15 March 2021); doi: $10.1117 / 12.2595458$

SPIE. Event: SPIE Medical Imaging, 2021, Online Only 


\title{
PROGRESS IN BIOMEDICAL OPTICS AND IMAGING
}

\section{Medical Imaging 2021}

\section{Ultrasonic Imaging and Tomography}

\author{
Brett C. Byram \\ Nicole V. Ruiter \\ Editors
}

\author{
15-19 February 2021 \\ Online Only, California, United States
}

Sponsored by

SPIE

Cooperating Organizations

AAPM-American Association of Physicists in Medicine (United States)

MIPS—Medical Image Perception Society (United States)

SIIM-Society for Imaging Informatics in Medicine (United States)

WMIS—World Molecular Imaging Society (United States)

Published by

SPIE

Volume 11602 
The papers in this volume were part of the technical conference cited on the cover and title page. Papers were selected and subject to review by the editors and conference program committee. Some conference presentations may not be available for publication. Additional papers and presentation recordings may be available online in the SPIE Digital Library at SPIEDigitalLibrary.org.

The papers reflect the work and thoughts of the authors and are published herein as submitted. The publisher is not responsible for the validity of the information or for any outcomes resulting from reliance thereon.

Please use the following format to cite material from these proceedings:

Author(s), "Title of Paper," in Medical Imaging 2021: Ultrasonic Imaging and Tomography, edited by Brett C. Byram, Nicole V. Ruiter, Proceedings of SPIE Vol. 11602 (SPIE, Bellingham, WA, 2021) Sevendigit Article CID Number.

ISSN: 1605-7422

ISSN: 2410-9045 (electronic)

ISBN: 9781510640337

ISBN: 9781510640344 (electronic)

Published by

SPIE

P.O. Box 10, Bellingham, Washington 98227-0010 USA

Telephone +1 3606763290 (Pacific Time) · Fax +1 3606471445

SPIE.org

Copyright (c) 2021, Society of Photo-Optical Instrumentation Engineers.

Copying of material in this book for internal or personal use, or for the internal or personal use of specific clients, beyond the fair use provisions granted by the U.S. Copyright Law is authorized by SPIE subject to payment of copying fees. The Transactional Reporting Service base fee for this volume is $\$ 21.00$ per article (or portion thereof), which should be paid directly to the Copyright Clearance Center (CCC), 222 Rosewood Drive, Danvers, MA 01923. Payment may also be made electronically through CCC Online at copyright.com. Other copying for republication, resale, advertising or promotion, or any form of systematic or multiple reproduction of any material in this book is prohibited except with permission in writing from the publisher. The CCC fee code is $1605-$ $7422 / 21 / \$ 21.00$.

Printed in the United States of America by Curran Associates, Inc., under license from SPIE.

Publication of record for individual papers is online in the SPIE Digital Library.

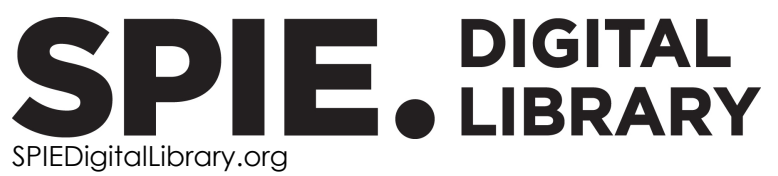

Paper Numbering: Proceedings of SPIE follow an e-First publication model. A unique citation identifier (CID) number is assigned to each article at the time of publication. Utilization of CIDs allows articles to be fully citable as soon as they are published online, and connects the same identifier to all online and print versions of the publication. SPIE uses a seven-digit CID article numbering system structured as follows:

- The first five digits correspond to the SPIE volume number.

- The last two digits indicate publication order within the volume using a Base 36 numbering system employing both numerals and letters. These two-number sets start with $00,01,02,03,04$, 05, 06, 07, 08, 09, 0A, OB ... 0Z, followed by 10-1Z, 20-2Z, etc. The CID Number appears on each page of the manuscript. 


\section{Contents}

ULTRASOUND IMAGE PROCESSING: JOINT SESSION WITH CONFERENCES 11596 AND 11602

$1160204 \quad$ Tailored methods for segmentation of intravascular ultrasound images via convolutional neural networks [1 1602-4]

$1160205 \quad$ Ultrasound GLCM texture analysis of radiation-induced acute toxicity following breast cancer radiotherapy [1 1602-5]

$1160206 \quad$ MPWC-Net++: evolution of optical flow pyramidal convolutional neural network for ultrasound elastography [1 1602-6]

\section{ULTRASOUND TOMOGRAPHY AND RECONSTRUCTION I}

$1160207 \quad$ Quantitative imaging network for versatile ultrasound tomography [1 1602-7]

1160208 Optimized source estimation for full waveform inversion in ultrasound computed tomography [11602-8]

1160209 DDN: dual domain network architecture for non-linear ultrasound transmission tomography reconstruction [1 1602-9]

$116020 \mathrm{~A} \quad$ Total attenuation compensation for backscatter coefficient estimation using full angular spatial compounding in physical phantoms [11602-10]

11602 OC Ultrasound computer tomography based tissue engineered blood vessel growth monitoring: a feasibility study [11602-12]

\section{CLINICAL APPLICATIONS OF ULTRASOUND AND US TOMOGRAPHY}

11602 OD Spatially tracked three-dimensional ultrasound imaging for monitoring the synovial membrane in knee arthritis [11602-13]

11602 OF Ultrasonic bubble detection and tracking using spatial coherence and motion modeling [1 1602-15]

11602 OG Analysis of timing results for 3D inverse scattering using transmission ultrasound [11602-16]

$11602 \mathrm{OH} \quad$ Deconvolution of ultrasound biomicroscopy images using generative adversarial networks to visualize and evaluate localization of ocular structures [11602-17] 
11602 Ol Planning and real-time monitoring of low intensity focused ultrasound therapies using a diagnostic imaging array [11602-18]

11602 0J Wireless oscillating device for power Doppler-based interstitial needle tip identification [11602-19]

11602 OK Deformable MRI-US image registration using biomechanically constrained shape matching network for image-guided prostate intervention [1 1602-20]

\section{BLOOD FLOW IMAGING}

$11602 \mathrm{OL} \quad$ Singular value decomposition processing for in vivo cardiac photoacoustic imaging [1 1602-22]

$116020 \mathrm{M} \quad$ Clutter filtering strategies for peripheral muscle perfusion imaging using ultrasound [11602-23]

$116020 \mathrm{~N} \quad$ Non-contrast power Doppler imaging with multidimensional clutter filtering for assessment of trans-arterial chemoembolization for hepatic malignancy [11602-24]

1160200 A novel, adaptive hierarchical clustering approach for independent component sorting for block-wise ICA filtering [1 1602-25]

11602 OP A coded excitation framework for increased signal-to-noise ratio of in vivo ultrasound power Doppler imaging [1 1602-26]

\section{IMAGE PROCESSING}

$116020 Q \quad$ Using ADMIRE to improve minimum variance performance in the presence of reverberation clutter [1 1602-1]

11602 OR Ultrasound strain imaging using spatiotemporal Bayesian regularized multi-level block matching method [1 1602-2]

11602 OS Deep classification of breast cancer in ultrasound images: more classes, better results with multi-task learning [1 $1602-3]$

\section{PHYSICS AND COMPUTER SIMULATIONS}

11602 OT Phase-insensitive ultrasound computed tomography for acoustic attenuation imaging of breast phantoms [1 1602-27]

11602 OU GPU-based simulation of echocardiography volumes using quantitative fiber-angle-tobackscatter measurements [11602-28] 
$116020 X \quad K$-wave simulations and their biomedical application in XACT imaging [11602-31]

\section{ULTRASOUND TOMOGRAPHY AND RECONSTRUCTION II}

11602 oY Sparsifying regularizations for stochastic sample average minimization in ultrasound computed tomography [11602-32]

$116020 Z$ Strain elastography with ultrasound computer tomography: a simulation study based on biomechanical models [1 1602-33]

$1160210 \quad$ Breast mass detection and classification using PRISM ${ }^{\top M}$ eXplainable network based machine learning (XNML) plafform for quantitative transmission (QT) ultrasound tomography [1 1602-34]

1160211 Acoustoelastic full-waveform inversion for transcranial ultrasound computed tomography [11602-35]

1160212 Preliminary result of spiral synthetic aperture based ultrasound computed tomography [11602-36]

1160213 An improved freehand 3D-ultrasound volume reconstruction technique for fast scans with scanline motion correction [1 1602-37]

\section{POSTER SESSION}

1160214 Segmentation of side branch regions in intravascular images using multi-modal information [11602-38]

1160215 Motion tracking in 3D ultrasound imaging based on Markov-like deep-learning-based deformable registration [1 1602-39]

1160216 Multi-needle detection in ultrasound image using max-margin mask R-CNN [1 1602-40]

1160218 Deep learning-based self-high-resolution for 3D ultrasound imaging (Cum Laude Poster Award) [11602-42]

1160219 Automatic tumor segmentation in 3D automated breast ultrasound using convolutional neural network [11602-43]

$116021 \mathrm{~A}$ Segmentation of intravascular ultrasound images by mask propagation network [11602-44]

$116021 \mathrm{~B} \quad$ Continuous blood flow monitoring using patch-type array transducer and portable ultrasound imaging system [1 1602-45]

$116021 \mathrm{C}$ Automatic detection of cotton balls during brain surgery: where deep learning meets ultrasound imaging to tackle foreign objects [1 1602-46]

$116021 \mathrm{D} \quad$ Acoustic reflector-based three-dimensional ultrasound imaging [11602-47] 
11602 1E Frequency-dependent calcium dynamics in ultrasound mechanotransduction [11602-48]

11602 IF Photoacoustic spectrum analysis based on k-Wave: simulation study [1 1602-49]

Proc. of SPIE Vol. 11602 1160201-6

Downloaded From: https://www.spiedigitallibrary.org/conference-proceedings-of-spie on 26 Apr 2023 Terms of Use: https://www.spiedigitallibrary.org/terms-of-use 